\title{
Sensitive Spectrophotometric Assay of Two Phosphodiesterase Type 5-Inhibitors in Pure and Dosage forms Using Potassium Permanganate
}

\author{
RAGAA EL SHIEKH ${ }^{1}$, ALAA S. AMIN ${ }^{2}$, EMAN M. HAFEZ ${ }^{1}$ and AYMAN A. GOUDA ${ }^{1 *}$ \\ ${ }^{1}$ Chemistry Department, Faculty of Sciences, Zagazig University, Zagazig, 44519, Egypt \\ ${ }^{2}$ Chemistry Department, Faculty of Sciences, Benha University, Benha, Egypt \\ aymangouda77@gmail.com
}

Received 31 May 2016 / Accepted 26 June 2016

\begin{abstract}
Rapid, simple and sensitive and validated spectrophotometric methods have been developed for the assay of two phosphodiesterase type 5-inhibitors; vardenafil HCl (VARD) and tadalafil (TDF) in pure and dosage forms. The proposed methods were based on the oxidation of both drugs by a known excess of potassium permanganate $\left(\mathrm{KMnO}_{4}\right)$ in acidic medium and estimating the unreacted permanganate by the reaction with a fixed amount of three dyes, amaranth, indigo carmine and methylene blue, in the same acid medium followed by measuring the absorbance at $\lambda_{\max }=520,610$ and $664 \mathrm{~nm}$, respectively. Different variables affecting the reaction were studied and optimized. The beer's law is obeyed in the concentration ranges of 2.0-12, 2.0-15 and 2.0-12 $\mu \mathrm{g} \mathrm{mL}^{-1}$ for VARD and 2.0-15, 2.0-20 and 2.0-12 $\mu \mathrm{g} \mathrm{mL}^{-1}$ for TDF using amaranth, indigo carmine and methylene blue methods, respectively with a correlation coefficient $\geq 0.9992$. The apparent molar absorptivity values are in the range $2.0956 \times 10^{4}, 1.2138 \times 10^{4}$ and $1.7502 \times 10^{4} \mathrm{~L} \mathrm{~mol}^{-1} \mathrm{~cm}^{-1}$ for VARD and $1.0769 \times 10^{4}, 0.7922 \times 10^{4}$ and $1.0918 \times 10^{4} \mathrm{~L} \mathrm{~mol}^{-1} \mathrm{~cm}^{-1}$ for TDF, using amaranth, indigo carmine and methylene blue methods, respectively. The limits of detection and quantification are reported. Intra-day and inter-day accuracy and precision of the methods have been evaluated. No interference was observed from the common tablet excipients. The methods were successfully applied to the assay of VARD and TDF in tablet preparations and the results were statistically compared with those of the reported methods by applying Student's $t$-test and F-test. The reliability of the methods was further ascertained by performing recovery studies using the standard addition method.
\end{abstract}

Keywords: Spectrophotometry, Vardenafil $\mathrm{HCl}$, Tadalafil, Potassium permanganate, Oxidation reactions, Tablets

\section{Introduction}

Vardenafil hydrochloride (VARD)is designated chemically aspiperazine, 1-[[3-(1,4-dihydro5-methyl-4-oxo-7-propylimidazo[5,1-f] [1,2,4]triazin-2-yl)-4-ethoxy-phenyl] sulfonyl]-4ethyl-, monohydrochloride and tadalafil (TDF) is designated chemically as(6R-trans)-6-(1,3benzodioxol-5-yl)- 2,3,6,7,12,12a- hexahydro-2-methyl-pyrazino [1', 2':1,6] pyrido[3,4- $b$ ] 
indole-1,4-dione (Figure 1). VARD and TDF are widely used as a selective phosphodiesterase type 5- inhibitor (PDE5) in the management of erectile dysfunction ${ }^{1,2}$. Extensive literature survey revealed that the determination of VARD and TDF in pure and dosage forms are not official in any of the pharmacopoeias and therefore, require much more investigation.

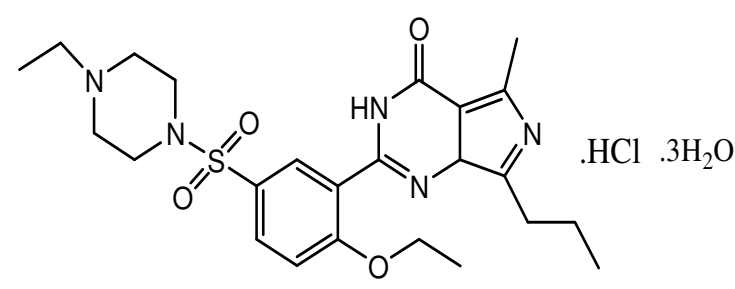

Vardenafilhydrochloride (VARD)

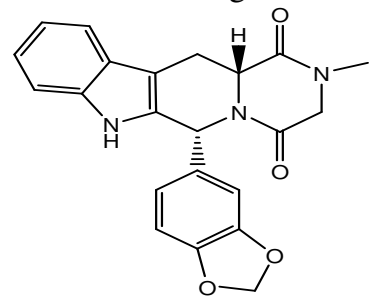

Tadalafil (TDF)

Figure 1. The chemical structure of vardenafil hydrochloride (VARD) and tadalafil (TDF)

Few reports for the determination of VARD in pure, tablet dosage forms and biological fluids have been developed with the help of a variety of analytical tools including high performance liquid chromatography (HPLC) $)^{3-12}$, gas chromatography ${ }^{13,14}$, capillary electrophoresis $^{15,16}$, electrochemical methods ${ }^{17,18}$ and atomic emission spectrometry ${ }^{19-21}$. Several analytical methods have been reported for the estimation of TDF in biological fluids or pharmaceutical dosage forms include HPLC ${ }^{22-34}$, liquid chromatography-tandem mass spectrometry with electrospray ionization ${ }^{35-37}$, micellar electro kinetic capillary chromatography $^{38}$ and atomic emission spectrometry ${ }^{20,21}$.

All the above methods developed for the quantification of VARD and TAD employed complex analytical instruments for their estimation mainly in bulk drug powders, tablet dosage forms and biological fluids. However, most of these methods are complex, require expensive experimental setup and skilled personnel, suffer from time-consuming procedures and are inaccessible to many laboratories in developing and under developed nations. In contrast, visible spectrophotometry is considered as the most convenient analytical technique in most quality control and clinical laboratories, hospitals and pharmaceutical industries for the assay of different classes of drugs in pure, pharmaceutical formulations and biological samples, due to its simplicity and reasonable sensitivity with significant economic advantages.

To the best of our knowledge, there are some methods have been reported for the quantification of VARD and TDF in commercial dosage forms using a spectrophotometric technique $^{38-50}$ (Table 1). However, these previously reported methods suffer from one or the other disadvantage such as poor sensitivity, depending on critical experimental variables, few methods require a rigid $\mathrm{pH}$ control and tedious and time-consuming liquid-liquid extraction step; some other methods have a relatively narrow dynamic linear range, involve a heating step, and/or use of expensive reagent or large amounts of organic solvents. For these reasons, it was worth while to develop a new, simple, cost effective and selective spectrophotometric method for the determination of VARD and TDF their pharmaceutical dosage forms.

The three dyes, amaranth, indigo carmine and methylene blue are well known for their high absorptivity and have been utilized for estimation of excess oxidant. The present work aims to develop a simple, rapid, sensitive, accurate, precise and cost-effective spectrophotometric methods for the estimation of two phosphodiesterase type 5-inhibitors, VARD and TDF in pure and dosage forms based on the discoloring redox reaction with an excess of $\mathrm{KMnO}_{4}$ and the determination of unreacted oxidant by the decrease in absorbance of the dyes; amaranth, indigo carmine and methylene blue. 
Table 1. Comparison between the report spectrophotometric method for determination of VARD and TDF

\begin{tabular}{|c|c|c|c|c|c|c|}
\hline Method & $\begin{array}{l}\text { Wavelength, } \\
\text { nm }\end{array}$ & $\begin{array}{l}\text { Beer's } \\
\text { law } \\
\mu \mathrm{g} \mathrm{mL}^{-1}\end{array}$ & $\begin{array}{c}\text { Molar } \\
\text { Absorptivity, } \\
\mathrm{L} \mathrm{mol}^{-1} \mathrm{~cm}^{-1} \\
\end{array}$ & $\begin{array}{l}\text { Detection } \\
\text { Limit, } \\
\mu \mathrm{g} \mathrm{mL} \\
\end{array}$ & Remarks & References \\
\hline \multicolumn{7}{|l|}{ VARD } \\
\hline $\begin{array}{l}\text { 3-Methyl-2-benzothiazolinone } \\
\text { hydrazone hydrochloride } / \mathrm{FeCl}_{3}\end{array}$ & 625 & $4.0-40$ & NA & 0.044 & $\begin{array}{c}\text { Less sensitive, less stable species } \\
\text { measured }\end{array}$ & 39 \\
\hline 4-Aminoantipyrine/potassium periodate & 530 & $4.0-60$ & NA & 0.035 & \multirow{6}{*}{$\begin{array}{l}\text { Required close } \mathrm{pH} \text { control and involved } \\
\text { extraction steps organic solvent is used }\end{array}$} & \multirow{6}{*}{40} \\
\hline BCG & 418 & $2.0-14$ & $2.471 \times 10^{4}$ & 0.56 & & \\
\hline $\mathrm{BCP}$ & 410 & $2.0-20$ & $1.302 \times 10^{4}$ & 0.49 & & \\
\hline BTB & 417 & $1.0-12$ & $4.594 \times 10^{4}$ & 0.27 & & \\
\hline $\mathrm{BPB}$ & 417 & $2.0-14$ & $3.284 \times 10^{4}$ & 0.53 & & \\
\hline MO & 429 & $1.0-20$ & $2.48 \times 10^{4}$ & 0.26 & & \\
\hline $\mathrm{KMnO}_{4} /(\mathrm{a})$ Amaranth & 520 & $2.0-15$ & $2.0956 \times 10^{4}$ & 0.59 & \multirow{3}{*}{$\begin{array}{l}\text { Highly sensitive and selective, no } \\
\text { heating orextraction step, Inexpensive } \\
\text { instrumental setup, use of ecofriendly } \\
\text { chemicals and aqueous system }\end{array}$} & \multirow{3}{*}{$\begin{array}{l}\text { Present } \\
\text { work }\end{array}$} \\
\hline (b) Indigocarmine & 610 & $2.0-20$ & $1.2138 \times 10^{4}$ & 0.48 & & \\
\hline (c) Methylene blue & 664 & $2.0-12$ & $1.7502 \times 10^{4}$ & 0.56 & & \\
\hline \multicolumn{7}{|l|}{ TDF } \\
\hline $\mathrm{Ce}(\mathrm{IV}) /$ methyl orange & 507 & $18-60$ & $1.0464 \times 10^{4}$ & 10.5 & \multirow[t]{2}{*}{ Less sensitive } & \multirow[t]{2}{*}{45} \\
\hline $\mathrm{N}$-bromosuccinamide/indigo carmine & 610 & $10-55$ & $1.4922 \times 10^{4}$ & 5.3 & & \\
\hline $\mathrm{Ce}(\mathrm{IV}) /$ Indigo carmine & 610 & $11-50$ & $0.8119 \times 10^{3}$ & 3.5 & \multirow[t]{2}{*}{ Less sensitive } & \multirow[t]{2}{*}{46} \\
\hline $\mathrm{Ce}(\mathrm{IV}) /$ methylene blue & 600 & $10-55$ & $0.8367 \times 10^{3}$ & 2.3 & & \\
\hline Bromocresol purple (BCP) & 410 & $2.0-16$ & $1.332 \times 10^{4}$ & 0.092 & \multirow{2}{*}{$\begin{array}{l}\text { Less sensitive, involves } \mathrm{pH} \\
\text { control, extraction step }\end{array}$} & \multirow[t]{2}{*}{47} \\
\hline Methyl orange (MO) & 425 & $2.0-20$ & $1.033 \times 10^{4}$ & 0.11 & & \\
\hline Bromothymol blue (BTB) & 420 & $10-50$ & NA & 2.23 & \multirow{2}{*}{$\begin{array}{l}\text { Less sensitive, involves } \mathrm{pH} \\
\text { control, extraction step }\end{array}$} & \multirow[t]{2}{*}{48} \\
\hline Bromocresol green (BCG) & 415 & $10-50$ & NA & 2.36 & & \\
\hline Isatin & 665 & $2.0-10$ & $7.70 \times 10^{3}$ & NA & \multirow[t]{2}{*}{ Less sensitive, use conc. $\mathrm{H}_{2} \mathrm{SO}_{4}$} & \multirow[t]{2}{*}{49} \\
\hline Xanthydrol & 640 & $4.0-20$ & $2.59 \times 10^{4}$ & NA & & \\
\hline $\begin{array}{l}\text { 3-Methyl-2-benzothiazoline } \\
\text { hydrazone (MBTH) }\end{array}$ & 676 & $2.0-12$ & NA & 0.0157 & Heating required & 50 \\
\hline $\mathrm{KMnO}_{4} /(\mathrm{a})$ Amaranth & 520 & $2.0-12$ & $1.0769 \times 10^{4}$ & 0.52 & \multirow{3}{*}{$\begin{array}{l}\text { Highly sensitive and selective, no } \\
\text { heating orextraction step, Inexpensive } \\
\text { instrumental setup, use of ecofriendly } \\
\text { chemicals and aqueous system }\end{array}$} & \multirow{3}{*}{$\begin{array}{l}\text { Present } \\
\text { work }\end{array}$} \\
\hline (b) Indigocarmine & 610 & $2.0-15$ & $0.7922 \times 10^{4}$ & 0.58 & & \\
\hline (c) Methylene blue & 664 & $2.0-12$ & $1.0918 \times 10^{4}$ & 0.50 & & \\
\hline
\end{tabular}




\section{Experimental}

All absorption spectra were made using Varian UV-Vis spectrophotometer (Cary 100 Conc., Australia) equipped with $10 \mathrm{~mm}$ quartz cell was used for absorbance measurements. This spectrophotometer has a wavelength accuracy of $\pm 0.2 \mathrm{~nm}$ with a scanning speed of $200 \mathrm{~nm} / \mathrm{min}$ and a band width of $2.0 \mathrm{~nm}$ in the wavelength range of 200-900 $\mathrm{nm}$.

\section{Materials and reagents}

All chemicals, solvents and reagents used in this work were of analytical reagent or pharmaceutical grade and all solutions were prepared fresh daily. Bidistilled water was used throughout the investigation.

\section{Reference standard of pure drugs}

Pharmaceutical grade VARD and TDF working standard was kindly supplied by their respective manufactures in Egypt, without any conflicts of interests in our submitted paper.

\section{Pharmaceutical formulations}

The following tablets were purchased from local commercial markets. Levitra tablets are labeled to contain $10 \mathrm{mg}$ VARD per tablet (Bayer Health Care Pharmaceuticals, Germany). Powerecta tablets are labeled to contain $20 \mathrm{mg}$ VARD per tablet (Eva Pharma Company Giza, Egypt). Verdenodeb tablets are labeled to contain $20 \mathrm{mg}$ VARD per tablet (Debeiky Pharmaceutical, Cairo, Egypt). Cialis ${ }^{\circledR}$ tablets, labeled to contain $20 \mathrm{mg}$ TDF per tablet (Eli Lilly, Australia). Snafi ${ }^{\circledR}$ tablets, labeled to contain $20 \mathrm{mg}$ TDF per tablet (Saudi Pharmaceutical Industries \& Medical Appliances Corporation (SPIMACO), Al-Qassim, Saudi Arabia.

\section{Standard solutions}

A stock standard solution $\left(100 \mu \mathrm{g} \mathrm{mL}^{-1}\right)$ of VARD and $\left(200 \mu \mathrm{g} \mathrm{mL} \mathrm{L}^{-1}\right)$ TDF was prepared by dissolving 10 and $20 \mathrm{mg}$ of pure VARD and TDF, respectively in bidistilled water and methanol, respectively further diluted to $100 \mathrm{~mL}$ with the same solvent in a $100 \mathrm{~mL}$ measuring flask. The standard solutions were found stable for at least one week without alteration when kept in an amber colored bottle and stored in a refrigerator when not in use.

\section{Reagents}

Potassium permanganate $\left(\mathrm{KMnO}_{4}\right)\left(5.0 \times 10^{-4} \mathrm{~mol} \mathrm{~L}^{-1}\right)$

A stock solution of $5.0 \times 10^{-4} \mathrm{~mol} \mathrm{~L}^{-1} \mathrm{KMnO}_{4}$ was freshly prepared by dissolving $0.079 \mathrm{~g}$ of $\mathrm{KMnO}_{4}$ (Sigma-Aldrich) in $10 \mathrm{~mL}$ of warm bidistilled water then completed to the mark in a $100 \mathrm{~mL}$ calibrated flask and standardized using sodiumoxalate ${ }^{51}$ and kept in a dark bottle and a refrigerator when not in use.

Sulfuric acid $\left(\mathrm{H}_{2} \mathrm{SO}_{4}\right)\left(2.0 \mathrm{~mol} \mathrm{~L}^{-1}\right)$

A $2.0 \mathrm{~mol} \mathrm{~L}^{-1}$ of $\mathrm{H}_{2} \mathrm{SO}_{4}$ was prepared by adding $10.8 \mathrm{~mL}$ of concentrated acid (Merck, Darmstadt, Germany, 98\%) to bidistilled water, cooled to room temperature, transfer to $100 \mathrm{~mL}$ with measuring flask, diluted to the mark and standardized as recorded ${ }^{52}$.

Dyes $\left(1000 \mu \mathrm{g} \mathrm{mL} \mathrm{L}^{-1}\right)$

A stock solutions $\left(1000 \mu \mathrm{g} \mathrm{mL}^{-1}\right)$ amaranth, indigo carmine and methylene blue were first prepared by dissolving accurately weighed $112 \mathrm{mg}$ of each dye (Sigma-aldrish, 90\% dye content) in bidistilled water and diluting to volume in a $100 \mathrm{~mL}$ calibrated flask. The solution was then diluted 5.0-fold and 10-fold to get the working concentration of 200 and $100 \mu \mathrm{g} \mathrm{mL}^{-1}$ of (amaranthor indigocarmine) and methylene blue, respectively. 


\section{Recommended general procedures}

\section{For VARD}

Different aliquots $(0.2-1.2 \mathrm{~mL}),(0.2-1.5 \mathrm{~mL})$ and $(0.2-1.2 \mathrm{~mL})$ of a standard $100 \mu \mathrm{g} \mathrm{mL}$ VARD solution using amaranth, indigo carmine and methylene blue methods, respectively, were transferred into a series of $10 \mathrm{~mL}$ calibrated flasks followed by adding $1.0 \mathrm{~mL} 2.0 \mathrm{~mol} \mathrm{~L}^{-1}$ $\mathrm{H}_{2} \mathrm{SO}_{4}$ and $1.5 \mathrm{~mL}$ of $\mathrm{KMnO}_{4}$ solution $\left(5.0 \times 10^{-4} \mathrm{~mol} \mathrm{~L}^{-1}\right)$ were added successively. The flasks were stoppered, content mixed and the flasks were kept aside for $5.0 \mathrm{~min}$ with occasional shaking. Finally, $1.5 \mathrm{~mL}$ of $\left(200 \mu \mathrm{g} \mathrm{mL}^{-1}\right)$ amaranth, indigo carmineor methylene blue solution was added to each flask and mixed well and then the volume was diluted to the mark with water. The decrease in color intensity of dyes were measure dspectrophotometrically after 3.0 min against a blank solution containing the same constituent except drug treated similarly, at their corresponding $\lambda_{\max } 520,610$ and $664 \mathrm{~nm}$ for amaranth, indigo carmine and methylene blue methods, respectively. The concentration range was determined in each case by plotting the concentration of VARD against absorbance at the corresponding maximum wavelengths.

\section{For TDF}

Different aliquots $(0.2-1.5 \mathrm{~mL}),(0.2-2.0 \mathrm{~mL})$ and $(0.2-1.2 \mathrm{~mL})$ of a standard $100 \mu \mathrm{g} \mathrm{mL}$ TDF solution using amaranth, indigocarmine and methylene blue methods, respectively, were transferred into a series of $10 \mathrm{~mL}$ calibrated flasks followed by adding $1.0 \mathrm{~mL} 2.0 \mathrm{~mol} \mathrm{~L}^{-1}$ $\mathrm{H}_{2} \mathrm{SO}_{4}$ and 1.0 and $1.5 \mathrm{~mL}$ of $\mathrm{KMnO}_{4}$ solution $\left(5.0 \times 10^{-4} \mathrm{~mol} \mathrm{~L}^{-1}\right)$ using methylene blue and (amaranth or indigocarmine), respectively were added successively. The flasks were stoppered, content mixed and the flasks were kept aside for 5.0 min with occasional shaking. Finally, 1.0, 1.2 and $1.5 \mathrm{~mL}$ of $\left(200 \mu \mathrm{g} \mathrm{mL}^{-1}\right)$ amaranth, indigo carmine and methylene blue solution, respectively were added to each flask and mixed well and then the volume was diluted to the mark with water. The decrease in color intensity of dyes were measured spectrophotometrically after 3.0 min against a blank solution containing the same constituent except drug treated similarly, at their corresponding $\lambda_{\max } 520,610$ and $664 \mathrm{~nm}$ for amaranth, indigo carmine and methylene blue methods, respectively. The concentration range was determined in each case by plotting the concentration of TDF against absorbance at the corresponding maximum wavelengths.

\section{Procedure for pharmaceutical formulations (tablets)}

The contents of twenty tabletsof each drug were weighed accurately and ground into a fine powder. An accurate weight of the powdered tablets equivalent to $20 \mathrm{mg}$ VARD was dissolved in bidistilled water or $20 \mathrm{mg}$ TDF was dissolved in methanol with shaking for 5.0 min and filtered using a Whatman No. 42 filter paper. The filtrate was diluted to the mark with bidistilled water for VARD or methanol for TDF in a $100 \mathrm{~mL}$ measuring flask to give and $200 \mu \mathrm{g} \mathrm{mL} \mathrm{m}^{-1}$ stock solution of VARD or TDF for analysis by spectrophotometric methods. A convenient aliquot was then subjected to analysis by the spectrophotometric procedures described above to determine the nominal content of the tablets using the corresponding regression equation of the appropriate calibration graph.

\section{Results and Discussion}

\section{Absorption spectra}

The spectrophotometric method for the determination of VARD and TDF involves two steps namely: 
1. Oxidation of the studied drugs with a known excess of $\mathrm{KMnO}_{4}$ in acidic medium at room temperature $\left(25 \pm 2{ }^{\circ} \mathrm{C}\right)$.

2. Determination of the residual $\mathrm{KMnO}_{4}$ by reacting it with a fixed amount of amaranth, indigocarmine and methylene blue dyes and measuring the absorbance of dyes at $\lambda_{\max }$ 520, 610 and $664 \mathrm{~nm}$ for amaranth, indigocarmine and methylene blue methods, respectively (Figure 2).

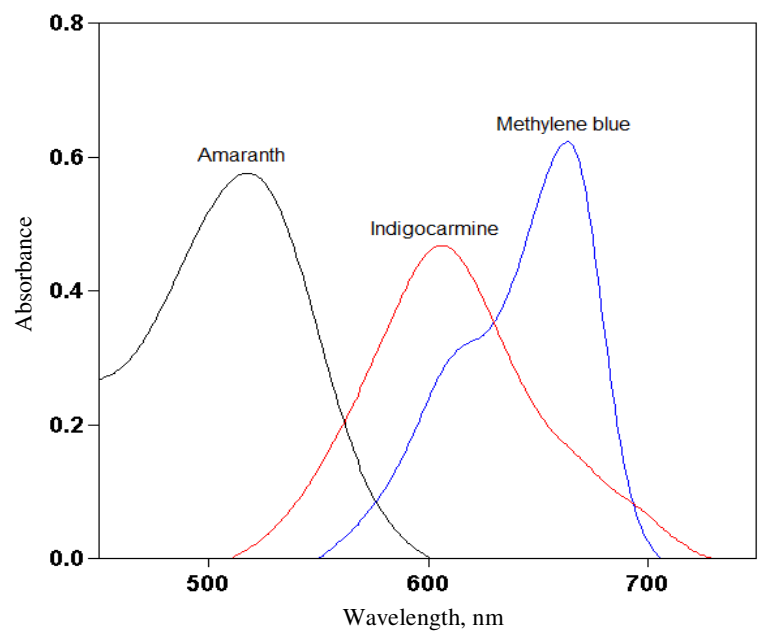

Figure 2. Absorption spectra for the unreacted oxidant that determined by reacting with a fixed amount of dyes and measuring the absorbance at 520, 610 and $664 \mathrm{~nm}$ for amaranth, indigocarmine and methylene blue methods, respectively in case of VARD

These methods make use of the bleaching action of $\mathrm{KMnO}_{4}$ on the dyes, the decolorization being caused by the oxidative destruction of the dyes. VARD or TDF when added in increasing concentrations to a fixed concentration of $\mathrm{KMnO}_{4}$ consumes the latter proportionally and there will be a concomitant decrease in the concentration of $\mathrm{KMnO}_{4}$. When a fixed concentration of dye is added to decreasing concentrations of $\mathrm{KMnO}_{4}$, a concomitant increase in the concentration of dye is obtained. Consequently, a proportional increase in the absorbance at the respective $\lambda_{\max }$ is observed with increasing concentrations of VARD or TDF. The tentative reaction scheme of spectrophotometric methods is shown in Scheme 1.

Drug + Known excess of $\mathrm{KMnO}_{4} \stackrel{\mathrm{H}^{+}}{\longrightarrow}$ Reaction product of drug + Unreacted $\mathrm{KMnO}_{4}$

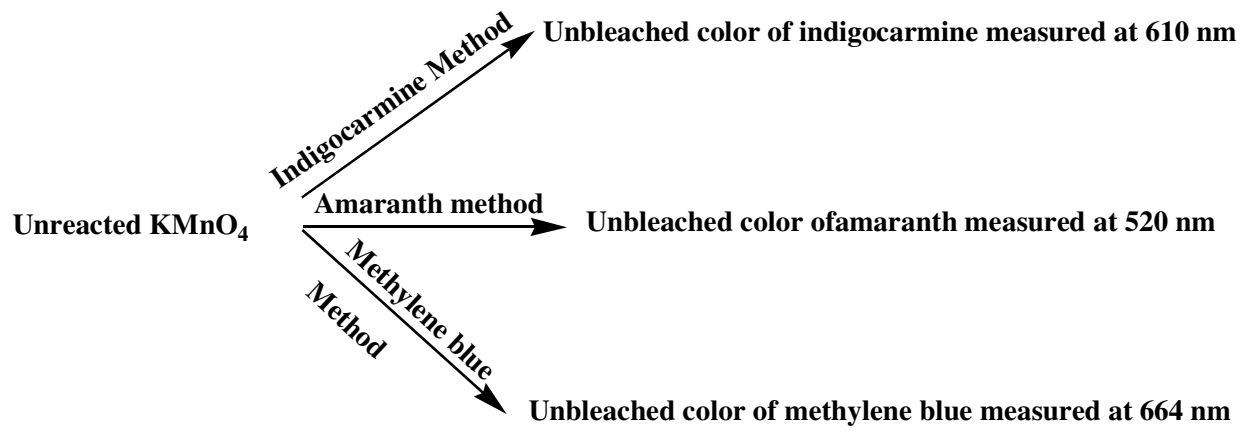

Scheme 1. Tentative reaction scheme for the proposed spectrophotometric methods 


\section{Optimization of variables}

The optimum conditions for the assay procedures and color development for each method have been established by varying the parameters one at a time, keeping the others fixed and observing the effect produced on the absorbance of the colored species.

\section{Effect of acid type and concentration}

To study the effect of acid concentration, different types of acids were examined $\left(\mathrm{H}_{2} \mathrm{SO}_{4}\right.$, $\mathrm{H}_{3} \mathrm{PO}_{4}$ and $\mathrm{CH}_{3} \mathrm{COOH}$ ) to achieve maximum yield of redox reaction. The results indicated that the sulphuric acid $\left(\mathrm{H}_{2} \mathrm{SO}_{4}\right)$ was the most suitable acid with $\mathrm{KMnO}_{4}$ as oxidant. Moreover, different volumes $(0.2-3.0 \mathrm{~mL})$ of $2.0 \mathrm{~mol} \mathrm{~L}^{-1} \mathrm{H}_{2} \mathrm{SO}_{4}$ were tested and found to be $1.0 \mathrm{~mL}$ of $2.0 \mathrm{~mol} \mathrm{~L}^{-1} \mathrm{H}_{2} \mathrm{SO}_{4}$ was ideal for the oxidation step in three methods and the same quantity of acid was employed for the estimation of the dye.

\section{Effect of $\mathrm{KMnO}_{4}$ concentration}

The influence of the volume of $5.0 \times 10^{-4} \mathrm{~mol} \mathrm{~L}^{-1} \mathrm{KMnO}_{4}$ on the reaction has been studied. It is apparent from Figure 3, that the absorbance increased with increasing volume of 5.0 $\times 10^{-4}$ mol L ${ }^{-1} \mathrm{KMnO}_{4}$ solution from $(0.25-3.0 \mathrm{~mL})$ and reached maximum when $1.5 \mathrm{~mL}$ of $\mathrm{KMnO}_{4}$ was added to a total volume of $10 \mathrm{~mL}$ forVARD (Figure 3) and 1.0 and $1.5 \mathrm{~mL}$ of $\mathrm{KMnO}_{4}$ solution were added to the total volume of $10 \mathrm{~mL}$ for TDF using methylene blue and (amaranth or indigocarmine), respectively.Therefore, it was found that maximum color intensity of the products was achieved with $1.5 \mathrm{~mL}$ of $5.0 \times 10^{-4} \mathrm{~mol} \mathrm{~L}^{-1} \mathrm{KMnO}_{4}$ for all measurements.

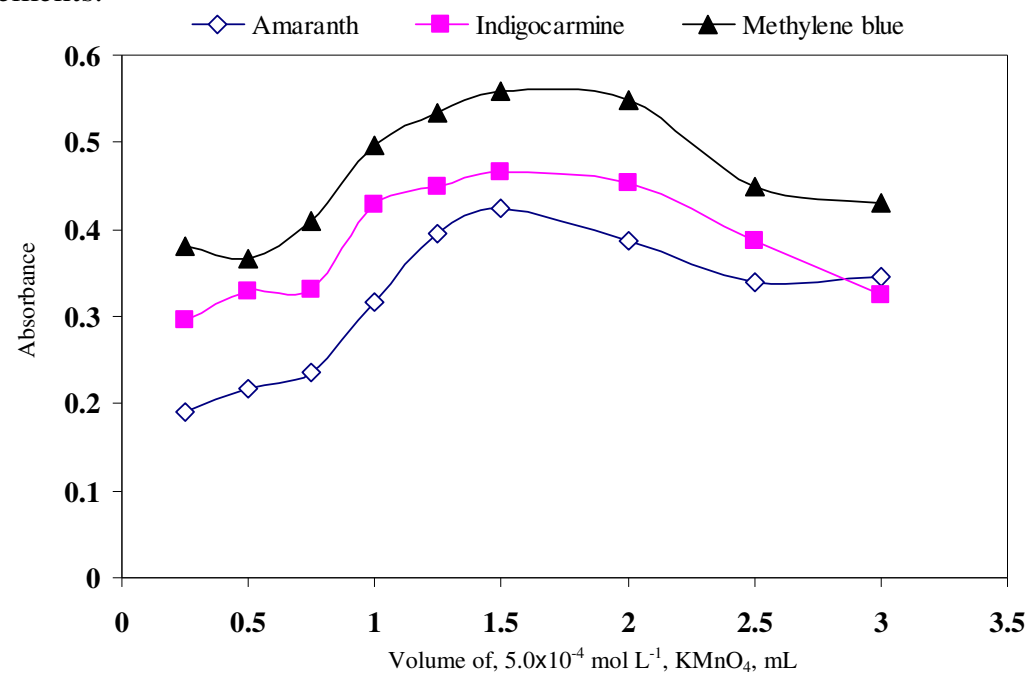

Figure 3. Effect of volume of $\mathrm{KMnO}_{4}\left(5.0 \times 10^{-4} \mathrm{molL}^{-1}\right)$ of the oxidation product of VARD with $\mathrm{KMnO}_{4}$ and dyes in $\mathrm{H}_{2} \mathrm{SO}_{4}$ medium

\section{Effect of dye concentration}

The effect of amaranth, indigo carmine and methylene blue concentration on the intensity of the color developed was carried out to obtain the optimum concentration of dyes that produces the maximum and reproducible color intensity by reducing the residual of $\mathrm{KMnO}_{4}$. The effect dye concentration was studied in the range of $0.25-3.0 \mathrm{~mL}$ of each dye $\left(200 \mu \mathrm{g} \mathrm{mL}^{-1}\right)$. It was found that maximum color intensity of the oxidation products was achieved with 1.5 
of each dye solution in case of VARD (Figure 4). Whereas, it was found that maximum color intensity of the oxidation products was achieved with 1.0, 1.2 and $1.5 \mathrm{~mL}$ of amaranth, indigo carmine and methylene blue dye solutions, respectively for TDF (Figure 5). The color was found to be stable up to $24 \mathrm{~h}$.

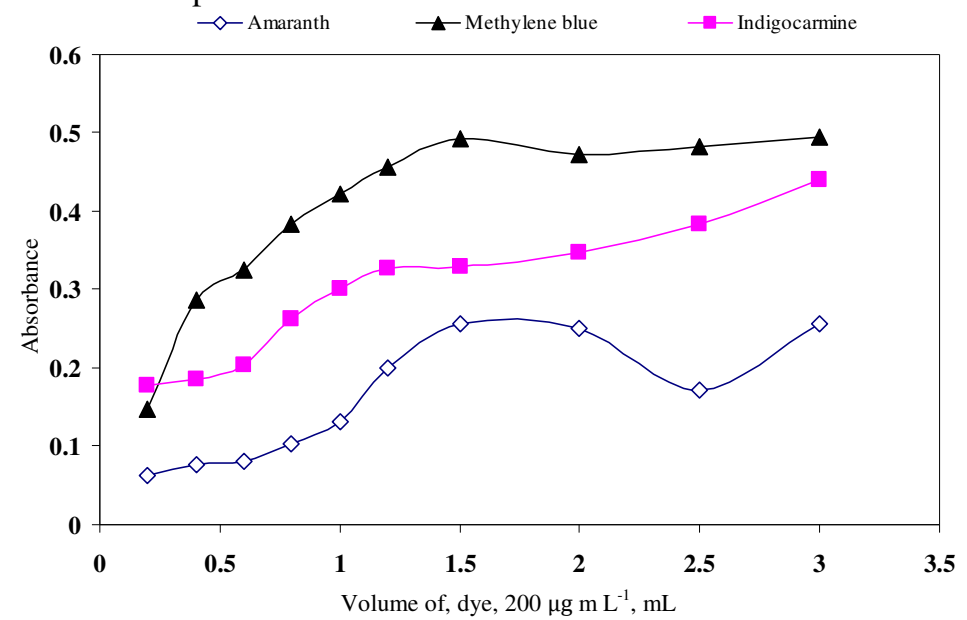

Figure 4. Effect of volume of dyes $\left(200 \mu \mathrm{g} \mathrm{mL}^{-1}\right)$ of the oxidation product of VARD with $\mathrm{KMnO}_{4}$ and dyes in $\mathrm{H}_{2} \mathrm{SO}_{4}$ medium

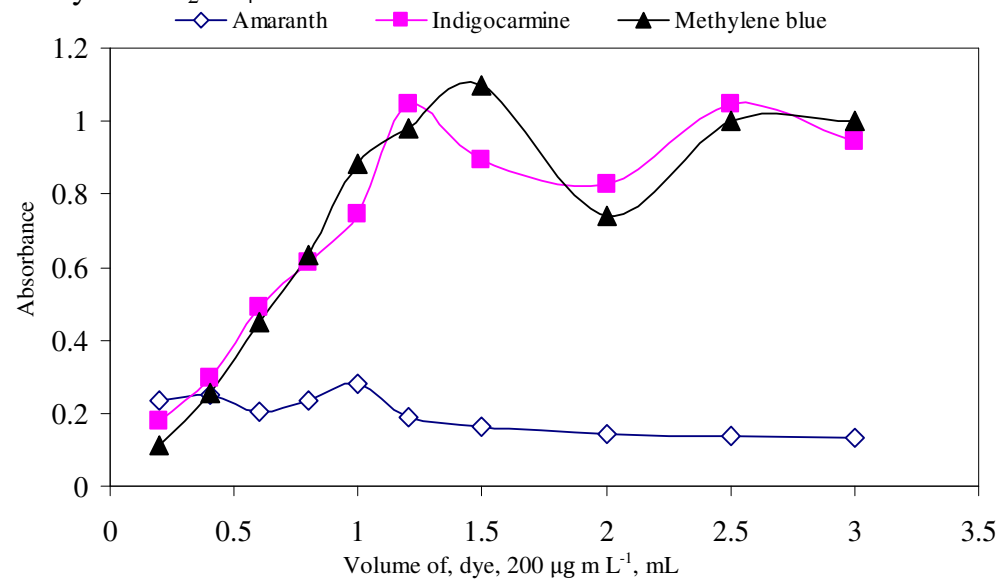

Figure 5. Effect of volume of dyes $\left(200 \mu \mathrm{g} \mathrm{mL}^{-1}\right)$ of the oxidation product of TDF with $\mathrm{KMnO}_{4}$ and dyes in $\mathrm{H}_{2} \mathrm{SO}_{4}$ medium

\section{Effect of temperature and mixing time}

The effect of temperature was studied by heating a series of sample and blank solutions at different temperatures ranging from 25 to $60{ }^{\circ} \mathrm{C}$ in water bath. It was found that raising the temperature does not accelerate the oxidation process and does not give reproducible results, so maximum color intensity was obtained at room temperature $\left(25 \pm 2{ }^{\circ} \mathrm{C}\right)$. The effect of mixing time required completing oxidation of the studied drugs and for reducing the excess oxidant was studied by measuring the absorbance of sample solution against blank solution prepared similarly at various time intervals $2.0-20 \mathrm{~min}$. It was found that the contact times gave constant and reproducible absorbance values at $5.0 \mathrm{~min}$ at room temperature $\left(25 \pm 2{ }^{\circ} \mathrm{C}\right)$ 
for both drugs. The time required for complete oxidation of the drug is not critical and any delay up to $15 \mathrm{~min}$ in the determination of unreacted $\mathrm{KMnO}_{4}$ had no effect on the absorbance. After oxidation process, $3.0 \mathrm{~min}$ standing time was found necessary for the complete bleaching of the dye color by the residual $\mathrm{KMnO}_{4}$ for both drugs and the absorbance of the unreacted dye was stable for at least $24 \mathrm{~h}$, there after.

\section{Effect of sequence of addition}

The optimum sequence of addition was $\mathrm{KMnO}_{4}-\mathrm{H}_{2} \mathrm{SO}_{4}$-drug-dye. Other sequences gave lower absorbance values under the same experimental conditions.

\section{Stoichiometric ratio}

The molar ratiomethod described by Yoe and Jones ${ }^{53}$ was employed to determine the stoichiometry of drug, oxidant and dyes. The molar ratio between oxidant and dye [Dye]/[O] at the selected conditions was carried out, by keeping the concentration of the oxidant constant $\left(1.5 \mathrm{~mL}\right.$ of $\left.5 \times 10^{-4} \mathrm{~mol} \mathrm{~L}^{-1}\right) \mathrm{KMnO}_{4}$ and the drug $\left(10 \mu \mathrm{g} \mathrm{mL}^{-1}\right)$ and variable volumes (0.1-2.0 mL) of dye $\left(5.0 \times 10^{-4} \mathrm{~mol} \mathrm{~L}^{-1}\right)$ were added. The absorbance was measured at the suitable wavelength against blank solution prepared by the same manner. The absorbance values were then plotted against the molar ratio $[\mathrm{Dye}] /[\mathrm{O}]$.

The molar ratio between the drug (VARD or TDF) and oxidant $[\mathrm{D}] /[\mathrm{O}]$ at the selected conditions was carried out, by keeping the concentration of the oxidant constant $(1.5 \mathrm{~mL}$ of $\left.5 \times 10^{-4} \mathrm{~mol} \mathrm{~L}^{-1}\right) \mathrm{KMnO}_{4}$ and $\left(1.5 \mathrm{~mL}\right.$ of $\left.5.0 \times 10^{-4} \mathrm{~mol} \mathrm{~L}^{-1}\right)$ dye and different volumes $(0.1$ $2.0 \mathrm{~mL})$ of the drug $\left(5.0 \times 10^{-4} \mathrm{~mol} \mathrm{~L}^{-1}\right)$ were added. The absorbance was measured at the suitable wavelength against blank solution prepared by the same manner. The absorbance values were then plotted against the molar ratio $[\mathrm{D}] /[\mathrm{O}]$. Experimental results showed that the inflection of the lines at stoichiometric ratio $(1: 1)$ for $[$ Dye $] /[O] ;(1.0: 2.0)[\mathrm{D}] /[\mathrm{O}]$ and (1.0:2.0)[D]/[Dye] as shown in Table 2 .

\section{Method validation}

The proposed methods have been validated for linearity, sensitivity, precision, accuracy, selectivity and recovery.

\section{Linearity and sensitivity}

Under the optimum conditions a linear correlation was found between absorbance at $\lambda_{\max }$ and the concentration of VARD and TDF in the ranges of $2.0-15$ and $2.0-20 \mu \mathrm{g} \mathrm{mL}^{-1}$, respectively. The calibration graph is described by the equation:

$$
\mathrm{A}=\mathrm{a}+\mathrm{bC}
$$

Where $\mathrm{A}=$ absorbance, $\mathrm{a}=$ intercept, $\mathrm{b}=$ slope and $\mathrm{C}=$ concentration in $\mu \mathrm{g} \mathrm{mL}^{-1}$, obtained by the method of least squares. Correlation coefficient, intercept and slope of the calibration data are summarized in Table 2. For accurate determination, Ringbom concentration range ${ }^{54}$ was calculated by plotting log concentration of drug in $\mu \mathrm{g} \mathrm{mL}^{-1}$ against transmittance \% from which the linear portion of the curve gives an accurate range of micro determination of VARD and TDF and represented in Table 2. Sensitivity parameters such as apparent molar absorptivity and Sandell's sensitivity values, as well as the limits of detection and quantification, were calculated as per the current $\mathrm{ICH}$ guidelines ${ }^{55}$ and illustrated in Table 2. The high molar absorptivity and lower Sandell sensitivity values reflect the good and high sensitivity of the proposed methods. The validity of the proposed methods was evaluated by statistical analysis ${ }^{56}$ between the results achieved from the 
proposed methods and that of the reported method. Regarding the calculated Student's $t$-test and variance ratio $F$-test (Table 2 ), there is no significant difference between the proposed and reported methods ${ }^{40,47}$ regarding accuracy and precision.

Table 2. Analytical and regression parameters of proposed oxidation spectrophotometric methods for determination of VARD and TDF

\begin{tabular}{|c|c|c|c|c|c|c|}
\hline \multirow[b]{2}{*}{ Parameters } & \multicolumn{3}{|c|}{ VARD } & \multicolumn{3}{|c|}{ TDF } \\
\hline & Amaranth & Indigocarmine & $\begin{array}{c}\text { Methylene } \\
\text { blue }\end{array}$ & Amaranth & Indigocarmine & $\begin{array}{c}\text { Methylene } \\
\text { blue }\end{array}$ \\
\hline $\begin{array}{c}\text { Beer's law limits, } \\
\mu \mathrm{g} \mathrm{mL} \mathrm{mL}^{-1}\end{array}$ & $2.0-12$ & $2.0-15$ & $2.0-12$ & $2.0-15$ & $2.0-20$ & $2.0-12$ \\
\hline $\begin{array}{c}\text { Ringboom limits, } \\
\qquad \mu \mathrm{g} \mathrm{mL}^{-1}\end{array}$ & $4.0-10$ & $4.0-12$ & $4.0-10$ & $4.0-12$ & $4.0-16$ & $4.0-10$ \\
\hline $\begin{array}{l}\text { Molar absorptivity, } \\
\times 10^{4} \mathrm{~L} \mathrm{~mol}^{-1} \mathrm{~cm}^{-1}\end{array}$ & 2.0956 & 1.2138 & 1.7502 & 1.0769 & 0.7922 & 1.0918 \\
\hline $\begin{array}{c}\text { Sandell } \\
\text { sensitivity, } \mathrm{ng} \mathrm{cm}^{-2} \\
\text { Regression } \\
\text { equation }^{\mathrm{a}}\end{array}$ & 26.80 & 46.35 & 32.08 & 36.16 & 49.15 & 35.67 \\
\hline Intercept (a) & 0.0056 & 0.0022 & 0.0014 & 0.0043 & 0.0044 & 0.0008 \\
\hline $\begin{array}{l}\text { Standard deviation } \\
\text { of intercept }\left(\mathrm{S}_{\mathrm{a}}\right)\end{array}$ & 0.009 & 0.023 & 0.016 & 0.009 & 0.02 & 0.008 \\
\hline Slope (b) & 0.0358 & 0.0211 & 0.0307 & 0.0262 & 0.0194 & 0.0281 \\
\hline $\begin{array}{l}\text { Standard deviation } \\
\text { of slope }\left(\mathrm{S}_{\mathrm{b}}\right)\end{array}$ & 0.018 & 0.015 & 0.027 & 0.013 & 0.017 & 0.012 \\
\hline $\begin{array}{l}\text { Correlation } \\
\text { coefficient, (r) }\end{array}$ & 0.9993 & 0.9994 & 0.9999 & 0.9991 & 0.9992 & 0.9998 \\
\hline Mean \pm SD & $100.81 \pm 1.06$ & $99.45 \pm 0.94$ & $100.42 \pm 0.89$ & $99.51 \pm 1.17$ & $99.73 \pm 1.41$ & $98.75 \pm 1.36$ \\
\hline RSD \% & 1.05 & 0.95 & 0.89 & 1.18 & 1.41 & 1.38 \\
\hline $\mathrm{RE} \%$ & 1.10 & 0.99 & 0.93 & 1.23 & 1.48 & 1.45 \\
\hline $\begin{array}{l}\text { Limit of detection, } \\
\qquad \mu \mathrm{g} \mathrm{mL}-1\end{array}$ & 0.59 & 0.48 & 0.56 & 0.52 & 0.58 & 0.50 \\
\hline $\begin{array}{c}\text { Limit of } \\
\text { quantification, } \\
\mu \mathrm{g} \mathrm{mL}^{-1}\end{array}$ & 1.97 & 1.60 & 1.87 & 1.73 & 1.93 & 1.67 \\
\hline Calculated $t$-value ${ }^{\mathrm{b}}$ & 1.03 & 1.66 & 0.34 & 0.19 & 0.08 & 1.08 \\
\hline Calculated $F$-value ${ }^{\mathrm{b}}$ & 3.58 & 2.82 & 2.53 & 1.21 & 1.19 & 1.11 \\
\hline$[$ Dye $] /[\mathrm{O}]$ & $1: 1$ & $1: 1$ & $1: 1$ & $1: 1$ & $1: 1$ & $1: 1$ \\
\hline [D]/[Dye] & $1: 2$ & $1: 2$ & $1: 2$ & $1: 2$ & $1: 2$ & $1: 2$ \\
\hline$[\mathrm{D}] /[\mathrm{Dye}]$ & $1: 2$ & $1: 2$ & $1: 2$ & $1: 2$ & $1: 2$ & $1: 2$ \\
\hline
\end{tabular}

${ }^{\mathrm{a}} A=a+b C$, where $C$ is the concentration in $\mu \mathrm{g} \mathrm{mL} \mathrm{m}^{-1}, A$ is the absorbance units, $a$ is the intercept, $b$ is the slope. ${ }^{\mathrm{b}}$ The theoretical values of $t$ and $F$ are 2.57 and 5.05, respectively at confidence limit at $95 \%$ confidence level and five degrees of freedom $(p=0.05)$.

The limits of detection (LOD) and quantification (LOQ) were calculated according to the same guidelines using the formulas ${ }^{55,56}$ :

$$
\mathrm{LOD}=3.3 \sigma / \mathrm{s} \text { and } \mathrm{LOQ}=10 \sigma / \mathrm{s}
$$


Where $\sigma$ is the standard deviation of five reagent blank determinations and $\mathrm{s}$ is the slope of the calibration curve.

\section{Accuracy and precision}

In order to evaluate the precision of the proposed methods, solutions containing three different concentrations of VARD and TDF were prepared and analyzed in six replicates. The analytical results obtained from this investigation are summarized in Table $3 \& 4$. Lower values of the relative standard deviation (R.S.D\%) and percentage relative error (R.E\%) indicate the precision and accuracy of the proposed methods. The percentage relative error is calculated using the following equation:

$$
\% \text { R.E }=\left[\frac{\text { found }- \text { taken }}{\text { taken }}\right] x 100
$$

The assay procedure was repeated six times and percentage relative standard deviation (R.S.D\%) values were obtained within the same day to evaluate repeatability (intra-day precision) and over five different days to evaluate intermediate precision (inter-day precision).

For the same concentrations of drugs inter- and intra-day accuracy of the methods was also evaluated. The percentage recovery values with respect to found concentrations of each drug were evaluated to ascertain the accuracy of the methods. The recovery values close to $100 \%$ as compiled in Table $3 \& 4$ shows that the proposed methods are very accurate.

Table 3. Results of intra-day and inter-day accuracy and precision study for VARD obtained by the proposed methods

\begin{tabular}{|c|c|c|c|c|c|}
\hline Method & $\begin{array}{c}\text { Taken } \\
\mu \mathrm{g} \mathrm{mL}^{-1} \\
\end{array}$ & $\begin{array}{c}\text { Recovery } \\
\%\end{array}$ & $\begin{array}{l}\text { Precision } \\
\text { RSD \% } \\
\end{array}$ & $\begin{array}{c}\text { Accuracy } \\
\text { RE \% }\end{array}$ & $\begin{array}{c}\text { Confidence } \\
\text { Limit }^{\mathrm{b}}\end{array}$ \\
\hline & \multicolumn{5}{|c|}{ Intra-day } \\
\hline \multirow{3}{*}{ Amaranth } & 4.0 & 99.00 & 0.56 & -1.0 & $3.960 \pm 0.023$ \\
\hline & 8.0 & 99.30 & 0.74 & -0.70 & $7.944 \pm 0.062$ \\
\hline & 12 & 99.20 & 1.02 & -0.80 & $11.904 \pm 0.127$ \\
\hline \multirow[t]{3}{*}{ Indigocarmine } & 4.0 & 99.10 & 0.67 & -0.90 & $3.964 \pm 0.028$ \\
\hline & 8.0 & 98.90 & 1.10 & -1.10 & $7.912 \pm 0.091$ \\
\hline & 12 & 100.20 & 1.25 & 0.20 & $12.024 \pm 0.158$ \\
\hline \multirow[t]{3}{*}{ Methylene blue } & 4.0 & 99.40 & 0.80 & -0.60 & $3.976 \pm 0.033$ \\
\hline & 8.0 & 99.00 & 0.97 & -1.0 & $7.920 \pm 0.081$ \\
\hline & 12 & 99.70 & 1.19 & -0.30 & $11.964 \pm 0.149$ \\
\hline \multirow{4}{*}{ Amaranth } & \multicolumn{5}{|c|}{ Inter-day } \\
\hline & 4.0 & 99.60 & 0.47 & -0.40 & $3.984 \pm 0.02$ \\
\hline & 8.0 & 99.80 & 0.82 & -0.20 & $7.984 \pm 0.069$ \\
\hline & 12 & 99.00 & 1.15 & -1.0 & $11.88 \pm 0.143$ \\
\hline \multirow[t]{3}{*}{ Indigocarmine } & 4.0 & 99.50 & 0.63 & -0.50 & $3.980 \pm 0.026$ \\
\hline & 8.0 & 99.40 & 0.96 & -0.60 & $7.952 \pm 0.080$ \\
\hline & 12 & 100.50 & 1.30 & 0.50 & $12.06 \pm 0.165$ \\
\hline \multirow[t]{3}{*}{ Methylene blue } & 4.0 & 100.30 & 0.75 & 0.30 & $4.012 \pm 0.032$ \\
\hline & 8.0 & 99.40 & 1.10 & -0.60 & $7.952 \pm 0.087$ \\
\hline & 12 & 99.10 & 1.60 & -0.90 & $11.892 \pm 0.20$ \\
\hline
\end{tabular}

${ }^{a} R S D \%$, percentage relative standard deviation; $R E \%$, percentage relative error. ${ }^{b}$ Mean \pm standard error 


\section{Robustness and ruggedness}

For the evaluation of method robustness, volume of $\mathrm{H}_{2} \mathrm{SO}_{4}$ was slightly altered $(1.0 \pm 0.2 \mathrm{~mL})$ and the reaction timewas slightly varied deliberately (5.0 $\pm 2.0 \mathrm{~min}$ ) (after adding $\mathrm{KMnO}_{4}$ ) in the three methods for each drug. The analysis was performed with altered conditions by taking three different concentrations of drugs and the methods were found to remain unaffected as shown by the RSD values in the ranges of $0.75-2.40 \%$ and $0.70-2.20 \%$ for VARD and TDF, respectively. Methods ruggedness was expressed as the RSD of the same procedure applied by three different analysts as well as using three different instruments (spectrophotometers). The inter-analysts RSD were in the ranges $0.80-2.20 \%$ and 0.60 $1.95 \%$ for VARD and TDF, respectively, whereas the inter-instruments RSD ranged from $0.80-2.40 \%$ and $0.90-2.30 \%$ for VARD and TDF, respectively suggesting that the developed methods were rugged. The results are shown in Table 5.

Table 4. Results of intra-day and inter-day accuracy and precision study for TDF obtained by the proposed methods

\begin{tabular}{lccccc}
\hline Method & $\begin{array}{c}\text { Taken } \\
\mu \mathrm{g} \mathrm{mL} \mathrm{mL}^{-1}\end{array}$ & $\begin{array}{c}\text { Recovery } \\
\%\end{array}$ & $\begin{array}{c}\text { Precision } \\
\text { RSD \% }\end{array}$ & $\begin{array}{c}\text { Accuracy } \\
\text { RE \% }\end{array}$ & $\begin{array}{c}\text { Confidence } \\
\text { Limit }^{\mathrm{b}}\end{array}$ \\
\cline { 2 - 6 } Amaranth & \multicolumn{4}{c}{ Intra-day } & \\
& 4.0 & 99.30 & 0.42 & -0.70 & $3.972 \pm 0.018$ \\
& 8.0 & 99.60 & 0.76 & -0.40 & $7.968 \pm 0.064$ \\
Indigocarmine & 12 & 99.40 & 0.90 & -0.60 & $11.928 \pm 0.113$ \\
& 5.0 & 99.10 & 0.68 & -0.90 & $4.955 \pm 0.035$ \\
Methylene blue & 10 & 99.00 & 1.10 & -1.0 & $9.90 \pm 0.114$ \\
& 15 & 100.40 & 1.35 & 0.40 & $15.06 \pm 0.213$ \\
& 4.0 & 100.30 & 0.70 & 0.30 & $4.012 \pm 0.029$ \\
Amaranth & 8.0 & 99.80 & 0.90 & -0.20 & $7.984 \pm 0.075$ \\
& 12 & 99.20 & 1.40 & -0.80 & $11.904 \pm 0.175$ \\
\cline { 2 - 6 } Indigocarmine & 4.0 & 99.30 & 0.53 & -0.70 & $3.972 \pm 0.022$ \\
& 8.0 & 99.50 & 0.69 & -0.50 & $7.960 \pm 0.058$ \\
& 12 & 99.10 & 1.08 & -0.90 & $11.892 \pm 0.135$ \\
Methylene blue & 5.0 & 100.20 & 0.49 & 0.20 & $5.01 \pm 0.026$ \\
& 10 & 99.30 & 0.78 & -0.70 & $9.93 \pm 0.081$ \\
& 15 & 100.30 & 1.25 & 0.30 & $15.045 \pm 0.197$ \\
& 4.0 & 99.20 & 0.60 & -0.80 & $3.968 \pm 0.025$ \\
& 8.0 & 99.60 & 0.88 & -0.40 & $7.968 \pm 0.074$ \\
& 12 & 99.00 & 1.32 & -1.0 & $11.88 \pm 0.165$ \\
\hline
\end{tabular}

${ }^{a} R S D \%$, percentage relative standard deviation; $R E \%$, percentage relative error. ${ }^{b}$ Mean \pm standard error

\section{Recovery studies}

To ascertain the accuracy, reliability and validity of the proposed methods, recovery experiment was performed through standard addition technique. This study was performed by spiking three different levels of pure drugs (50,100 and 150\% of the level present in the tablet) to a fixed amount of drugs in tablet powder (pre-analysed) andthe total concentration was found by the proposed methods. The determination with each level was repeated three times and the percent recovery of the added standard was calculated from: 


$$
\% \text { Recovery } \frac{\left[\mathrm{C}_{\mathrm{F}}-\mathrm{C}_{\mathrm{T}}\right]}{C_{p}} x 100
$$

Where $C_{F}$ is the total concentration of the analyte found, $C_{T}$ is a concentration of the analyte present in the tablet preparation; $C_{P}$ is a concentration of analyte (pure drugs) added to tablets preparations. The results of this study presented in Table 6 revealed that the accuracy of the proposed methods was unaffected by the various excipients present in tablets which did not interfere in the assay.

Table 5. Results of method robustness and ruggedness (all values in RSD\%) studies for VARD and TDF

\begin{tabular}{|c|c|c|c|c|c|}
\hline \multirow{4}{*}{ Methods } & \multirow{4}{*}{$\begin{array}{c}\text { Nominal } \\
\text { amount } \\
\text { concentration, } \\
\mu \mathrm{g} \mathrm{mL}^{-1}\end{array}$} & \multicolumn{4}{|c|}{$\mathrm{RSD} \%$} \\
\hline & & \multicolumn{2}{|c|}{ Robustness } & \multicolumn{2}{|c|}{ Ruggedness } \\
\hline & & \multicolumn{4}{|c|}{ Variable alerted $^{\mathrm{a}}$} \\
\hline & & $\begin{array}{c}\text { Acid } \\
\text { volume } \\
(n=3)\end{array}$ & $\begin{array}{l}\text { Reaction } \\
\text { time }(n=3)\end{array}$ & $\begin{array}{c}\text { Different } \\
\text { analysts } \\
(n=3)\end{array}$ & $\begin{array}{c}\text { Different } \\
\text { instruments } \\
(\mathrm{n}=3)\end{array}$ \\
\hline \multirow{4}{*}{ Amaranth } & \multicolumn{5}{|c|}{ VARD } \\
\hline & 4.0 & 1.20 & 0.75 & 0.80 & 0.90 \\
\hline & 8.0 & 1.62 & 1.25 & 1.50 & 1.30 \\
\hline & 12 & 2.10 & 1.80 & 1.90 & 2.30 \\
\hline \multirow[t]{2}{*}{ Indigocarmine } & 4.0 & 1.10 & 0.90 & 1.20 & 0.80 \\
\hline & 8.0 & 1.40 & 1.70 & 1.54 & 1.30 \\
\hline & 12 & 2.20 & 2.10 & 1.90 & 2.30 \\
\hline \multirow[t]{3}{*}{ Methylene blue } & 4.0 & 1.15 & 0.95 & 0.80 & 1.05 \\
\hline & 8.0 & 1.80 & 1.50 & 1.60 & 1.70 \\
\hline & 12 & 2.40 & 2.00 & 2.20 & 2.40 \\
\hline \multirow{4}{*}{ Amaranth } & \multicolumn{5}{|c|}{ TDF } \\
\hline & 4.0 & 0.80 & 0.70 & 0.90 & 1.10 \\
\hline & 8.0 & 1.25 & 1.40 & 1.30 & 1.60 \\
\hline & 12 & 1.90 & 2.15 & 1.80 & 2.20 \\
\hline \multirow[t]{3}{*}{ Indigocarmine } & 5.0 & 0.75 & 0.95 & 0.60 & 1.20 \\
\hline & 10 & 1.60 & 1.20 & 1.10 & 1.70 \\
\hline & 15 & 2.10 & 1.70 & 1.75 & 2.30 \\
\hline \multirow[t]{3}{*}{ Methylene blue } & 4.0 & 0.92 & 0.84 & 1.05 & 0.90 \\
\hline & 8.0 & 1.45 & 1.30 & 1.55 & 1.30 \\
\hline & 12 & 2.20 & 2.00 & 1.95 & 2.15 \\
\hline
\end{tabular}

$\overline{{ }^{a}}$ Volume of $\left(5.0 \mathrm{~mol} \mathrm{~L}^{-1}\right) \mathrm{HCl}$ is $(1.0 \pm 0.2 \mathrm{~mL})$ and reaction time is $(5.0 \pm 2.0 \mathrm{~min})$ (after adding $\mathrm{NBS}$ ) were used

\section{Application of pharmaceutical formulations (tablets)}

The proposed methods were applied to the determination of VARD and TDF in pharmaceutical formulations (tablets). The results in Table 7 showed that the methods are successful for the determination of VARD and TDF and that the excipients in the dosage forms do not interfere. A statistical comparison of theresults obtained from the assay of VARD and TDF by the proposed methods and the reported methods ${ }^{40,47}$ for the same batch of material is presented in Table 7. The results agree well with the label claim and also were in agreement with the results obtained by the reported methods ${ }^{40,47}$. When the results were statistically compared with those of the reported methods by applying the Student's $t$-test for 
accuracy and $F$-test for precision, the calculated $t$-value and $F$-value at $95 \%$ confidence level did not exceed the tabulated values for five degrees of freedom ${ }^{56}$. Hence, no significant difference between the proposed methods and the reported methods at the $95 \%$ confidence level with respect to accuracy and precision.

Table 6. Results of recovery experiments by standard addition method for the determination of VARD and TDF in tablets using the proposed methods

\begin{tabular}{|c|c|c|c|c|c|c|c|c|}
\hline \multirow[b]{2}{*}{ Samples } & \multirow{2}{*}{$\begin{array}{c}\text { Taken } \\
\text { drug in } \\
\text { tablet } \\
\mu \mathrm{g} \mathrm{mL}^{-1}\end{array}$} & \multirow[b]{2}{*}{$\begin{array}{c}\text { Pure drug } \\
\text { Added } \\
\mu \mathrm{g} \mathrm{mL} L^{-1}\end{array}$} & \multicolumn{2}{|c|}{ Amaranth } & \multicolumn{2}{|c|}{ Methylene blue } & \multicolumn{2}{|c|}{ Indigocarmine } \\
\hline & & & $\begin{array}{c}\text { Total } \\
\text { found } \\
\mu \mathrm{g} \mathrm{mL}-1\end{array}$ & $\begin{array}{l}\text { Recovery }{ }^{\mathrm{a}} \\
(\%) \pm \mathrm{SD}\end{array}$ & $\begin{array}{c}\text { Total } \\
\text { found } \\
\mu \mathrm{g} \mathrm{mL}^{-1}\end{array}$ & $\begin{array}{l}\text { Recovery }^{\mathrm{a}} \\
(\%) \pm \mathrm{SD}\end{array}$ & $\begin{array}{c}\text { Total } \\
\text { found } \\
\mu \mathrm{g} \mathrm{mL} L^{-1}\end{array}$ & $\begin{array}{l}\text { Recovery }^{\mathrm{a}} \\
(\%) \pm \mathrm{SD}\end{array}$ \\
\hline Levitra & 4.0 & 2.0 & 5.976 & $99.60 \pm 0.40$ & 5.952 & $99.20 \pm 0.65$ & 5.988 & $99.80 \pm 0.40$ \\
\hline tablets & 4.0 & 4.0 & 7.976 & $99.70 \pm 0.72$ & 7.96 & $99.50 \pm 0.87$ & 7.928 & $99.10 \pm 0.57$ \\
\hline$(10 \mathrm{mg})$ & 4.0 & 6.0 & 10.02 & $100.20 \pm 0.86$ & 9.90 & $99.00 \pm 1.08$ & 10.05 & $100.50 \pm 0.73$ \\
\hline Powerecta & 4.0 & 2.0 & 6.012 & $100.20 \pm 0.39$ & 5.964 & $99.40 \pm 0.54$ & 5.958 & $99.30 \pm 0.55$ \\
\hline tablets & 4.0 & 4.0 & 8.064 & $100.80 \pm 0.58$ & 7.976 & $99.70 \pm 0.67$ & 8.072 & $100.90 \pm 0.70$ \\
\hline (20 mg) & 4.0 & 6.0 & 9.89 & $98.90 \pm 0.63$ & 10.0 & $100.00 \pm 0.86$ & 9.91 & $99.10 \pm 0.90$ \\
\hline Verdenodeb & 4.0 & 2.0 & 5.94 & $99.00 \pm 0.60$ & 6.048 & $100.80 \pm 0.50$ & 5.94 & $99.00 \pm 0.85$ \\
\hline tablets & 4.0 & 4.0 & 8.056 & $100.70 \pm 0.88$ & 7.968 & $99.60 \pm 0.76$ & 7.936 & $99.20 \pm 0.96$ \\
\hline \multirow[t]{3}{*}{$(20 \mathrm{mg})$} & 4.0 & 6.0 & 9.96 & $99.60 \pm 1.10$ & 9.91 & $99.10 \pm 1.25$ & 10.05 & $100.50 \pm 1.30$ \\
\hline & Taken & & \multicolumn{2}{|c|}{ Amaranth } & \multicolumn{2}{|c|}{ Methylene blue } & \multicolumn{2}{|c|}{ Orange $\mathrm{G}$} \\
\hline & $\begin{array}{l}\text { drug in } \\
\text { tablet } \\
\mu \mathrm{g} \mathrm{mL} \mathrm{m}^{-1}\end{array}$ & $\begin{array}{l}\text { Added } \\
\mu \mathrm{g} \mathrm{mL}^{-1}\end{array}$ & $\begin{array}{c}\text { Total } \\
\text { found } \\
\mu \mathrm{g} \mathrm{mL}-1\end{array}$ & $\begin{array}{l}\text { Recovery }^{a} \\
(\%) \pm \mathrm{SD}\end{array}$ & $\begin{array}{c}\text { Total } \\
\text { found } \\
\mu \mathrm{g} \mathrm{mL}^{-1}\end{array}$ & $\begin{array}{c}\text { Recovery }^{\mathrm{a}} \\
(\%) \pm \mathrm{SD}\end{array}$ & $\begin{array}{c}\text { Total } \\
\text { found } \\
\mu \mathrm{g} \mathrm{mL}^{-1}\end{array}$ & $\begin{array}{l}\text { Recovery }^{\mathrm{a}} \\
(\%) \pm \mathrm{SD}\end{array}$ \\
\hline Cialis $^{\circledR}$ & 4.0 & 2.0 & 5.964 & $99.40 \pm 0.65$ & 6.03 & $100.50 \pm 0.35$ & 5.952 & $99.20 \pm 0.65$ \\
\hline tablets & 4.0 & 4.0 & 8.016 & $100.20 \pm 0.90$ & 7.968 & $99.60 \pm 0.60$ & 8.056 & $100.70 \pm 0.90$ \\
\hline (20 mg) & 4.0 & 6.0 & 9.98 & $99.80 \pm 1.17$ & 10.03 & $100.30 \pm 1.10$ & 10.10 & $101.00 \pm 1.40$ \\
\hline $\operatorname{Snafi}^{\circledR}$ & 4.0 & 2.0 & 6.036 & $100.60 \pm 0.52$ & 5.97 & $99.50 \pm 0.44$ & 5.982 & $99.70 \pm 0.63$ \\
\hline tablets & 4.0 & 4.0 & 7.928 & $99.10 \pm 0.85$ & 7.888 & $98.60 \pm 1.10$ & 8.04 & $100.50 \pm 0.80$ \\
\hline$(20 \mathrm{mg})$ & 4.0 & 6.0 & 10.13 & $101.30 \pm 1.30$ & 9.95 & $99.50 \pm 1.50$ & 9.93 & $99.30 \pm 1.20$ \\
\hline
\end{tabular}

Table 7. Results of analysis of tablets by the proposed methods for the determination of VARD and TDF and statistical comparison with the reference methods

\begin{tabular}{|c|c|c|c|c|}
\hline \multirow[t]{3}{*}{ Samples } & \multicolumn{4}{|c|}{ Recovery $^{\mathrm{a}}, \% \pm \mathrm{SD}$} \\
\hline & \multicolumn{3}{|c|}{ Proposed Methods } & \multirow{2}{*}{$\begin{array}{l}\text { Reported } \\
\text { methods }\end{array}$} \\
\hline & Amaranth & $\begin{array}{c}\text { Methylene } \\
\text { blue }\end{array}$ & $\begin{array}{c}\text { Indigo } \\
\text { carmine }\end{array}$ & \\
\hline $\begin{array}{l}\text { Levitra tablets } \\
\text { (10 mg VARD) }\end{array}$ & $99.30 \pm 0.35$ & $99.60 \pm 0.45$ & $100.40 \pm 0.80$ & $99.92 \pm 0.64^{[40]}$ \\
\hline$t$-value ${ }^{b}$ & 1.9 & 0.91 & 1.04 & \\
\hline$F$-value ${ }^{b}$ & 3.34 & 2.02 & 1.56 & \\
\hline $\begin{array}{l}\text { Powerectatablets ( } 20 \\
\text { mg VARD) }\end{array}$ & $100.50 \pm 0.80$ & $99.50 \pm 0.30$ & $99.20 \pm 0.90$ & $99.90 \pm 0.67^{[40]}$ \\
\hline$t$-value $e^{b}$ & 1.28 & 1.21 & 1.39 & \\
\hline$F$-value ${ }^{b}$ & 1.42 & 4.98 & 1.80 & \\
\hline $\begin{array}{l}\text { Verdenodebtablets } \\
\text { (20 mg VARD) }\end{array}$ & $99.10 \pm 0.85$ & $99.70 \pm 0.50$ & $99.80 \pm 0.93$ & $99.50 \pm 0.72^{[40]}$ \\
\hline$t$-value ${ }^{b}$ & 0.8 & 0.51 & 0.57 & \\
\hline$F$-value ${ }^{b}$ & 1.39 & 2.07 & 1.66 & \\
\hline
\end{tabular}




\begin{tabular}{|c|c|c|c|c|}
\hline & Amaranth & $\begin{array}{c}\text { Methylene } \\
\text { blue }\end{array}$ & Orange $\mathrm{G}$ & \multirow[b]{2}{*}{$99.79 \pm 0.56^{[47]}$} \\
\hline $\begin{array}{l}\text { Cialis }^{\circledR} \text { tablets (20 } \\
\text { mg TDF) }\end{array}$ & $100.40 \pm 0.30$ & $99.40 \pm 0.78$ & $100.10 \pm 0.74$ & \\
\hline$t$-value ${ }^{b}$ & 2.14 & 0.90 & 0.74 & \\
\hline$F$-value ${ }^{b}$ & 3.48 & 1.94 & 1.74 & \\
\hline $\begin{array}{l}\text { Snafi }^{\circledR} \text { tablets (20 mg } \\
\text { TDF) }\end{array}$ & $99.30 \pm 0.68$ & $100.20 \pm 0.75$ & $99.43 \pm 0.40$ & $99.60 \pm 0.51^{[47]}$ \\
\hline$t$-value $e^{b}$ & 0.78 & 1.47 & 0.58 & \\
\hline$F$-value ${ }^{b}$ & 1.77 & 2.16 & 1.62 & \\
\hline
\end{tabular}

${ }^{a}$ Average of six determinations. ${ }^{b}$ The theoretical values of $t$ and $F$ are 2.571 and 5.05 , respectively at confidence limit at $95 \%$ confidence level and five degrees of freedom $(p=0.05)$

\section{Conclusion}

Three new, useful simple, rapid, and cost-effective spectrophotometric methods have been developed for determination of VARD and TDF in bulk drugs and in their tablets using $\mathrm{KMnO}_{4}$ as oxidizing agent and validated as per the current $\mathrm{ICH}$ guidelines. The present spectrophotometric methods are characterized by simplicity of operation, high selectivity, comparable sensitivity, low-cost instrument, they do not involve any critical experimental variable and are free from tedious and time-consuming extraction steps and use of organic solvents unlike many of the previous methods reported for VARD and TDF. The assay methods have some additional advantages involve less stringent control of experimental parameters such as the stability of the colored system, accuracy, reproducibility, time of analysis, temperature independence and cheaper chemicals. These advantages encourage the application of the proposed methods in routine quality control analysis of VARD and TDF in pure and dosage forms.

\section{Conflict of interest}

The authors declare that they have no conflict of interests with the company name used in the paper.

\section{References}

1. Abdel-Aziz A A M, Asiri Y A, El-Azab A S, Al-Omar M A and Kunieda T, Anal Profiles Drug Subst Excipients, 2011, 36, 287-329; DOI:10.1016/B978-0-12-387667-

2. Ashour A E, Rahman A F M M and Kassem M G, Anal Profiles Drug Subst Excipients, 2014, 39, 515-544; DOI:10.1016/B978-0-12-800173-8.00009-X

3. Aboul-Enein H Y, Ghanem A and Hoenen H, J Liq Chromatogr Relat Technol, 2005, 28, 593-604.

4. Zou P, Oh SS, Hou P, Low M and Koh H, J Chromatogr A, 2006, 1104(1-2), 113 122; DOI:10.1016/j.chroma.2005.11.103

5. Zhu X, Xiao S, Chen B, Zhang F, Yao S, Wan Z, a Yang D and Han H, J Chromatogr A, 2005, 1066(1-2), 89-95; DOI:10.1016/j.chroma.2005.01.038

6. Zhang Z, Kang S, Xu M, Ma M, Chen B and Yao S, Se Pu., 2005, 23(4), 358-361.

7. Subba Rao D V, Surendranath K V, Radhakrishnanand P, Suryanarayana M V and Raghuram P, Chromatographia, 2008, 68(9-10), 829-835; DOI:10.1365/s10337-0080766-4

8. Bartošová Z, Jirovský D and Horna A, J Chromatogr A., 2011, 1218(44), 7996-8001; DOI:10.1016/j.chroma.2011.09.001 
9. Lake S T, Altman P M, Vaisman J and Addison R S, Biomed Chromatogr, 2010, 24(8), 846-851; DOI:10.1002/bmc.1375

10. Manisha G, Usha P and Vandana P, Am J Pharm Tech Res., 2013, 3, 928.

11. Di Y, Zhao M, Nie Y, Wang F and Lv J, J Autom Methods Manag Chem., 2011, 1-6; DOI:10.1155/2011/982186

12. Kumar K K, Rao C K, Reddy Y R.K and Mukkanti K A, Am J Anal Chem., 2012, 3, 59.

13. Papoutsis I, Nikolaou P, Athanaselis S, Pistos C, Maravelias C and Spiliopoulou C, $J$ Mass Spectrom., 2011, 46(1), 71-76; DOI:10.1002/jms.1868

14. Strano-Rossi S, Anzillotti L, de la Torre X and Botrè F, Rapid Commun Mass Spectrom., 2010, 24(11), 1697; DOI:10.1002/rcm.4568.

15. Idris A M and Alnajjar A O, Acta Chromatogr, 2007, 19, 97.

16. Flores J R, Nevado J J B, Penalvo G C and Diez N M, J Chromatogr B, 2004, 811(2), 231-236; DOI:10.1016/j.jchromb.2004.07.016

17. Uslu B B, Dogan, S A, Ozkan and Aboul-Enein H Y, Anal Chim Acta, 2005, 552(12), 127-134; DOI:10.1016/j.aca.2005.07.040

18. Ghoneim M M, Hassanein A M, Salahuddin N A, El-Desoky H S and El fiky M N, $J$ Solid State Electrochem., 2013, 17(3), 891-897; DOI:10.1007/s10008-012-1939-5

19. Khalil S, MikrochemicaActa, 2007, 158,233.

20. Mohammed S K H and Shalaby N M, J Pharm Bio Sci., 2013, 4(1), 1037.

21. Mohammed S K H, Al zahrani S S, Hussein Y M and Turkestani A I, Anal Chem An Indian J, 2014, 14, 201.

22. Unnisa A, Babu Y, Suggu S K and Chaitanya S, J Appl Pharm Sci., 2014, 4, 72.

23. Gao W, Zhang Z, Li Z and Liang G, J Chromatogr Sci., 2007, 45, 540-543; DOI:10.1093/chromsci/45.8.540

24. Farthing C A, Farthing D E, Koka S, Larus T, Fakhry I, Xi L, Kukreja R C, Sica D, and Gehr T W, J Chromatogr B Analyt Technol Biomed Life Sci., 2010, 878(28), 2891-2895; DOI:10.1016/j.jchromb.2010.07.022

25. Barot T G and Patel P K, J AOAC Int., 2010, 93(2), 516-522.

26. Mehanna M M, Motawaa A M and Samaha M W, J AOAC Int., 2012, 95, 1064-1068; DOI:10.5740/jaoacint.11-083

27. Gudipati E, Mahaboob S D, Nunna B R, Ashok K V and Rambabu K, Res Desk, 2012, 1, 66-73.

28. Meejung P and Suyoun A, J Forensic Sci., 2012, 57, 637-640; DOI:10.1111/j.15564029.2012.02164.x

29. Alivelu S, Santhosh P, Sowmya M, Sravanthi C and Nageshwar M, J Chem Pharm Res., 2013, 5(4), 315-318

30. Prasanna R B, Amarnadh R K and Reddy M S, Res Pharm Biotechnol., 2010, 2, 1-6.

31. Kannappan N, Deepthi Y, Divya Y, Shashikanth S and Mannavalan R, Int J Chem Tech Res., 2010, 2, 329-333.

32. Sonawane P H, Panzade P S and Kale M A, Indian J Pharm Sci, 2013, 75, 230-233.

33. Patel J K and Patel N K, Sci Pharm., 2014, 82, 749-763; DOI:10.3797/scipharm.1403-22

34. Aboul-Enein $\mathrm{H}$ Y and Ali I, Talanta, 2005, 65, 276-280; DOI:10.1016/j.talanta.2004.06.012

35. Ramakrishna N V, Vishwottam K N and Puran S, J Chromatogr B Analyt Technol Biomed Life Sci., 2004, 809(2), 243-249; DOI:10.1016/j.jchromb.2004.06.026

36. Gratz S R, Flurer C L and Wolnik K A, J Pharm Biomed Anal, 2004, 36(3), 525-533; DOI:10.1016/j.jpba.2004.07.004 
37. Jomoorthy K and Challa B R, Der Pharmacia Lettre, 2012, 4, 1401-1413.

38. Rodriguez FJ, Berzas NJJ, Castenada PG and Mora DN, J Chromatogr B AnalytTechnol Biomed Life Sci, 2004, 811, 231.

39. Sunil Kumara A V V N K, Reddyb T V and Sekaranc C B, Anal Bioanal Chem Res., 2016, 3(1), 29-39.

40. El Sheikh R, Zaky M, Gouda AA and Abo Al Ezz S, J Chil Chem Soc., 2014, 59(1), 2248-2251; DOI:10.4067/S0717-97072014000100002

41. Abdel-Moety M M, Souaya E R and Soliman E A, J Pharm Pharm Sci., 2015, 4, 120.

42. Savjiyani N B and Patel P B, J Pharm Res., 2013, 3(5), 3652-3668

43. Ahmed N R, Baghdad Sci J., 2013, 10(3), 1005-1013.

44. Yunoos M, Sankar D G, Kumar B P and Hameed S, J Chem,. 2010, 7, 833; DOI:10.1155/2010/630576

45. Fraihat S, Discovery, 2014, 22(73), 45-48.

46. Fraihat S, Int J Pharm Pharm Sci., 2014, 6(7), 443-445.

47. Kaf A A and Gouda A A, Chem Ind Chem Engin Quart, 2011, 17, 125-132.

48. Nesalin A J J, Babu J G C, Kumar V G and Mani T T, J Chem., 2009, 6, 611-614; DOI:10.1155/2009/983146

49. Lakshmi V N, Kumar D R, Vardhan S V M and Rambabu C, Orient J Chem., 2009, 25(3), 791-794.

50. Anumolu P K D, Kavitha A, Durga D V, Bindu S H Sunitha G and Ramakrishna K, Anal Chem An Indian J., 2013, 13, 361.

51. Basset J, Denny R C, Jeffery G H and Mendham J, Vogel's Text Book of Quantitative Inorganic analysis. $4^{\text {th }}$ Edn., Prectice Hall, London, 1986; 350.

52. Jeffery G H, Bassett J, Mendham J and Denney R C, Titrimetric analysis. In Vogel's a text book of quantitative inorganic analysis, $5^{\text {th }}$ Ed., ELBS: London, 1989; 308.

53. Yoe J H and Jones A L, Ind End Chem Anal Ed., 1944, 16(2), 111-115; DOI:10.1021/i560126a015

54. Ringbom A, Z Anal Chem., 1939, 115, 332-343.

55. International Conference on Harmonisation of Technical Requirements for Registration of Pharmaceuticals for Human Use. ICH Harmonized Tripartite Guideline, Validation of Analytical Procedures: Text and Methodology Q2(R 1), Complementary Guideline on Methodology, London, November 2005.

56. Miller JN and Miller JC, "Statistics and chemometrics for analytical chemistry" $5^{\text {th }}$ Ed., Prentice Hall, England, 2005. 